\title{
濃赤色イチゴ新品種 ‘真紅の美鈴’の果実品質およびアントシアニン色素
}

\author{
水野真二 ${ }^{1 *}$ ・成川 昇 ${ }^{2} \cdot$ 近藤春美 ${ }^{1} \cdot$ 上吉原裕亮 ${ }^{1} \cdot$ 立石 亮 $^{1} \cdot$ \\ 窪田 聡 $^{1} \cdot$ 新町文絵 ${ }^{1} \cdot$ 渡辺慶一 $^{1}$ \\ ${ }^{1}$ 日本大学生物資源科学部 252-0880 神奈川県藤沢市亀井野 \\ 2ナルケンいちご園２99-3251 千葉県大網白里市大網
}

\section{Anthocyanin Pigments and Quality of the Deep Red Strawberry Cultivar 'Shinku-no-misuzu'}

\author{
Shinji Mizuno $^{1 *}$, Noboru Narukawa ${ }^{2}$, Harumi Uto-Kondo ${ }^{1}$, Yusuke Kamiyoshihara ${ }^{1}$, \\ Akira Tateishi ${ }^{1}$, Satoshi Kubota ${ }^{1}$, Fumie Shinmachi ${ }^{1}$ and Keiichi Watanabe ${ }^{1}$ \\ ${ }^{1}$ College of Bioresource Sciences, Nihon University, Kameino, Fujisawa, Kanagawa 252-0880 \\ ${ }^{2}$ Naruken Strawberry Farm, Oami, Oamishirasato, Chiba 299-3251
}

\begin{abstract}
The deep red strawberry cultivar 'Shinku-no-misuzu' was newly bred from a crossing between 'Fusanoka' and 'Reiko', and was characterized regarding aspects of the flowering time, yield, and fruit quality under forcing culture in Kanagawa Prefecture. 'Shinku-no-misuzu' exhibited slightly slower floral bud differentiation than the conventional cultivar 'Tochiotome', but showed high fruit hardness and a $>20$ brix/acid ratio. Relatively large amounts of glucose and fructose accumulated in 'Shinku-nomisuzu' fruit. The total anthocyanin content of the fruit was $185 \mu \mathrm{g} \cdot \mathrm{g}-1 \mathrm{FW}$, which reached around three-fold the content of 'Tochiotome'. The higher amount of anthocyanins, which are also known as antioxidants, in 'Shinku-no-misuzu' did not boost the total antioxidant activity of juice. Because $>80 \%$ of anthocyanins were composed of pelargonidin glycosides in all cultivars investigated, the deep red color of 'Shinku-no-misuzu' fruit may not have been due to the anthocyanin composition but simply to the higher anthocyanin content.
\end{abstract}

Key Words : antioxidant activity, breeding, forcing culture, polyphenol, yield キーワード : 育種, 抗酸化活性，ポリフェノール，収量，促成栽培

\section{1. 品種開発の背景}

近年，日本のイチゴは多品種化が進行して拈り，公設試 験場，民間会社，個人育種家などによる育種が盛んに行わ れている，イチゴの育種目標としては，大果性，良食味 性，早生性，多収性，病害抵抗性，輸送性といった形質が 一般に追求されるものの, 近年は果実の色, 成分, 芳香な どに従来品種とは異なる特徵を持つ品種が登場している. 例えば，“和田初こい’（商標名「初恋の香り」）や“淡雪” は果皮色がそれぞれ淡紅色拈よび淡橙色を呈する品種であ り，いずれも希少性の高い「白いちご」として一般に認知 されている。 ‘括いCベリ一’（曾根ら，2017）はアスコル ビン酸（ビタミンC）を多く含み，10倍体品種の“桃薰” （野口ら，2011）はモモ様の芳香を有していることから, これらの機能性や香りの特徵を生かして利用されている.

このよらな特徴的な品種が普及する中, 本報の著者であ る成川は，濃赤色果を特徵とする一季成り性イチゴ品種

2019 年 11 月 29 日 受付. 2020 年 6 月 4 日 受理. 本報告の一部は園芸学会平成 30 年度春季大会で発表した。

* Corresponding author. E-mail: mizuno.shinji@nihon-u.ac.jp
“真紅の美鈴’を個人で育成した．本品種は果色の濃さを 選抜基準として育成されたものではないが，その色の特徵 を生かした利用が千葉県内などの産地で始まっている。そ こで本論文では ‘真紅の美鈴’ の育成経過に加え, 関東地 方での促成栽培に拈ける栽培特性，果実品質拈よび果実に 含まれるアントシアニン色素の成分などについて従来品種 と比較し，その特徵を明らかにしたので報告する。

\section{2. 育成経過}

品種の育成経過を第 1 図に示す。育成は千葉県大網白里 市のパイプハウスで行った。良食味性を備える‘劣さの 香”を母親に，現在広く普及している“とち抏とめ’や “紅ほっぺ”などの祖先にあたり，大果性を備える“麗紅” （成川ら，1981）を父親にした交配後代の実生（ $F_{1} ）$ を2003 年 4 月に得て，同年 9 月に 150 株を定植した。2004 年は草 勢が強く，果実が硬くて食味が優れるといら基準で 25 個 体を選抜した．各個体からランナーで増殖した 10～20株 程度を 1 つ系統とし，2005 年から 2007 年にかけて系統 選抜を行った，選抜の基準は，個体選抜時の基準に加えて 果数が多く，概ね年内から収穫できる早生性を有し，果形 が正円錐形であるものとした。最終的に選抜された ‘C5- 


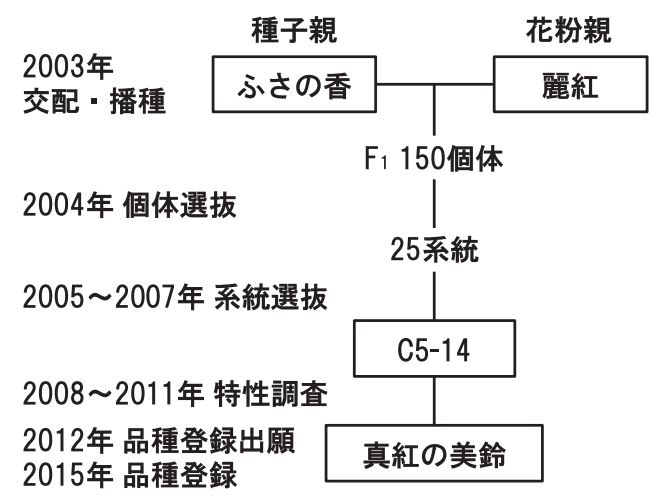

第1図“真紅の美鈴” の育成経過

14’は，促成栽培に向く一定の早生性，多収性括よび果実 品質を備えるとともに，果皮色拈よび果肉色が極めて濃い 赤色を呈する（第2図）といら特性を有していた。 この果 色は選抜基準にない想定外の形質であったものの，千葉県 内の数軒の生産者执よびその直売所利用者が ‘C5-14’の 食味を絶賛したことから，本系統を新品種として有望と判 断した。 2011 年 10 月 27 日に育成者である成川が“真紅の 美鈴” と命名して品種登録出願（出願番号第26416 号）を 行い，2012年 2 日 20 日に出願公表され，2015年 2 月 3 日 に品種登録（登録番号第 23452 号）された。

“真紅の美鈴” の普及拡大にあたっては，栽培特性や果 実品質に関する学術的な知見が望まれるため, 後述のとお り日本大学に抢いて特性調査を実施した。

\section{3. 栽培特性}

\section{1）花芽分化および開花特性}

日本大学生物資源科学部（神奈川県藤沢市）で2016〜 2018 年の各年度に調査を実施した。育苗は雨よけ八ウス で行い，毎年 6 月上旬から 7 月下旬にかけて親株から発生 した子株を $9 \mathrm{~cm}$ 径ポリポットに鉢受けし，7月末に親株か ら切り離して苗を養成した. 鉢受け後は概ね 1 か月間隔で

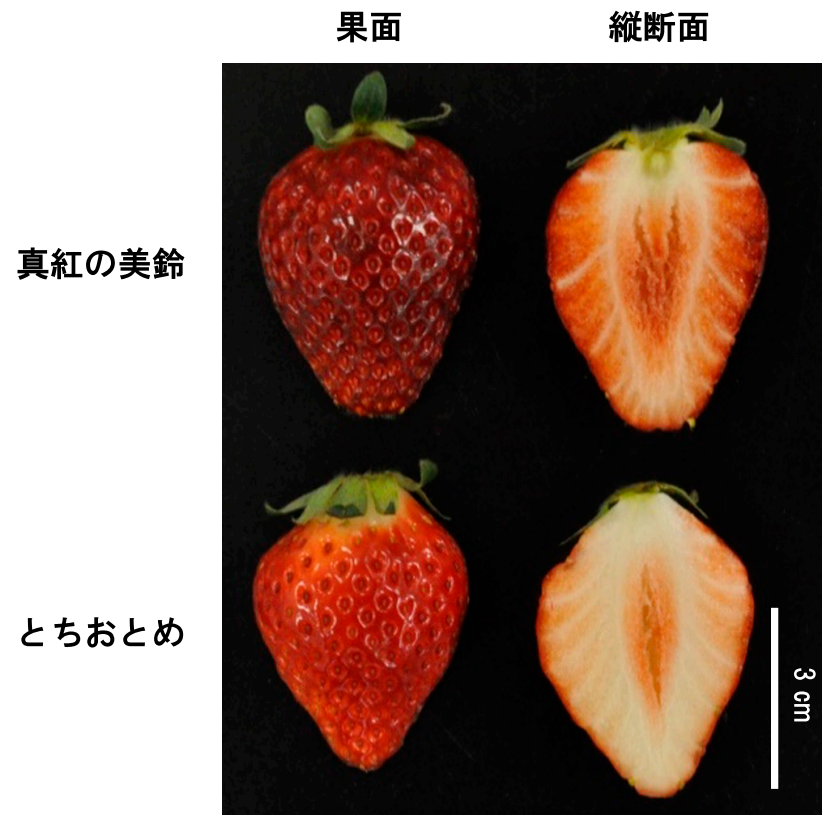

第2図 “真紅の美鈴’扣よび‘とち拈とめ’の果実

粒状化成肥料を株元に追肥し，1 回当たりの施肥量は成分 量で窒素，りん酸，カリともに約 $60 \mathrm{mg}$ /株とした. 最終の 追肥時期は 8 月上旬とした。 2018 年度のみ “真紅の美鈴” の一部の苗で夜冷短日育苗を行い，8月9日から 8 月 31 日 までの 22 日間，プレハブ冷蔵庫に苗を入出庫して日長 8 時間（17 時入庫，翌朝 9 時出庫), 夜温 $14^{\circ} \mathrm{C}$ となるよう に処理した。処理後は定植まで雨よけハウスで管理した.

夜冷短日育苗でない普通育苗の “真紅の美鈴’ は, 2016～2018年度のいずれの試験に拈いても同じ定植日に 花芽分化調査した“とち拓とめ’ と比べて花芽の分化や発 達が進んでいない傾向がみられ，2016年度は9月 12 日時 点で 5 株中 3 株が，2018 年度は 9 月 10 日時点で 5 株中 5 株が花芽未分化であった (第 1 表)。一方，年度を問わず 9 月 19 日以降に調査した株ではすべて花芽分化していた.

第1表 “真紅の美鈴’および‘とち括とめ’の花成の進展および収穫始期

\begin{tabular}{|c|c|c|c|c|c|c|c|c|c|c|c|c|}
\hline \multirow{2}{*}{ 年度 } & \multirow{2}{*}{ 栽培体系 } & \multirow{2}{*}{ 品種 } & \multirow{2}{*}{ 定植日 } & \multirow{2}{*}{\multicolumn{5}{|c|}{ 定植時花芽分化指数 ${ }^{\mathrm{z}}$}} & \multicolumn{3}{|c|}{ 半数開花日 ${ }^{\mathrm{y}}$} & \multirow{2}{*}{ 収穫始期 x } \\
\hline & & & & & & & & & 頂花房 & & 第一腋花房 & \\
\hline \multirow{2}{*}{2016} & \multirow{2}{*}{ 普通育苗＋無加温ハウス栽培 } & 真紅の美鈴 & \multirow{2}{*}{9 月 12 日 } & 1 & 1 & 0 & 0 & 0 & 11 月 26 日 & \multirow{2}{*}{$* \mathrm{w}$} & \multirow[b]{2}{*}{-} & 1 月 3 日 \\
\hline & & とちおとめ & & 4 & 3 & 2 & 2 & 1 & 11 月 5 日 & & & 12 月 13 日 \\
\hline \multirow{2}{*}{2017} & \multirow{2}{*}{ 普通育苗＋加温八ウス栽培 } & 真紅の美鈴 & \multirow{2}{*}{ 9月 19 日 } & 2 & 2 & 2 & 1 & 1 & 11 月 11 日 & & \multirow{2}{*}{ - } & 12 月 21 日 \\
\hline & & とちおとめ & & 4 & 4 & 3 & 2 & 2 & 11 月 8 日 & & & 12 月 16 日 ${ }^{n s}$ \\
\hline \multirow{4}{*}{2018} & \multirow{2}{*}{ 普通育苗＋加温八ウス栽培 } & 真紅の美鈴 & \multirow{2}{*}{ 9月 20 日 } & 4 & 3 & 3 & 2 & 1 & 11 月 3 日 & \multirow[b]{2}{*}{ ns } & 1 月 21 日 & 12 月 6 日 \\
\hline & & とちおとめ & & 6 & 6 & 5 & 5 & 1 & 11 月 2 日 & & 1 月 15 日 ${ }^{n s}$ & 11 月 29 日 \\
\hline & \multirow{2}{*}{$\begin{array}{l}\text { 夜冷短日育苗＋加温ハウス栽培 } \\
\text { 普通育苗＋加温ハウス栽培 }\end{array}$} & \multirow{2}{*}{ 真紅の美鈴 } & \multirow{2}{*}{9 月 10 日 } & 7 & 7 & 6 & 6 & 4 & 10 月 13 日 & \multirow{2}{*}{ 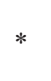 } & 1月 7 日 & 11 月 6 日 \\
\hline & & & & 0 & 0 & 0 & 0 & 0 & 12 月 16 日 & & 2 月 4 日 ${ }^{*}$ & 12 月 3 日 \\
\hline
\end{tabular}

${ }^{\mathrm{z}} 5$ 株の成長点を検鏡し，0:未分化， $1:$ 肥厚期， $2:$ 分化期，3: 花房分化期， $4:$ がく片形成期， $5:$ 花弁形成期，6:雄ずい形成期,

7 : 雌ずい形成期として評価

$\mathrm{y}$ 各反復内の $50 \%$ の株で花房内頂花が咲いた日の平均，一は未調査

$\mathrm{x}$ 各反復内の累積の収穫果数が 10 株当たり 5 果を超えた日の平均

w*はt検定により $5 \%$ 水準で有意差あり, ns は有意差なし 
なお，2018年度に括いて夜冷短日育苗を行った 真紅の 美鈴’では，9月 10 日時点でがく片形成期以降まで花芽が 発達していた。

パイプハウスに畧間 $105 \mathrm{~cm}$, ベッド幅 $65 \mathrm{~cm}$, 通路幅 $40 \mathrm{~cm}$, ベッド高 $30 \mathrm{~cm}$ の土耕栽培用の畧を作り，株間 $20 \mathrm{~cm}$, 条間 $25 \mathrm{~cm}, 2$ 条で本葉数 $3 \sim 4$ 枚に調整した苗を 定植した. 施肥は緩効性肥料（180日タイプ）の全量基肥 とし, $10 \mathrm{a}$ 当たり成分量は窒素, リン酸, カリともに $12 \mathrm{~kg}$ とした，9月末までに銀色ポリエチレンフィルムで畧をマ ルチングした． $50 \%$ の株で花房内頂花が咲いた日を半数開 花日とし, 累積の收穫果数が 10 株当たり 5 果を超えた日 を収穫始期とした。試験規模は 1 区 12 株，4反復とした。

2016年度は, 定植時点で花芽未分化の株が多かった“真 紅の美鈴’ は ‘とち抢とめ’ と比べて頂花房の半数開花日， 収穫始期がいずれも2 21 日遅れた。2017年度は, “真紅の美 鈴’ と ‘とち抢とめ’ の頂花房の半数開花日はいずれも 11 月 10 日頃，収穫始期はいずれも 12 月 20 日頃であった。 2018 年度は，9月 20 日に定植した ‘真紅の美鈴” と ‘とち 抢之め’ の頂花房の半数開花日は同等であり, 収穫始期は “真紅の美鈴’が‘とち抏とめ’より 7 日遅かったものの， いずれも 12 月上旬には収穫可能であった。 な拈，夜冷短 日育苗を行った ‘真紅の美鈴” は, 頂花房の半数開花日が 10 月 13 日，収穫始期が 11 月 6 日まで早まった。

\section{2）収量性}

調査は $6 \mathrm{~g}$ 以上の果実を対象に収穫開始から毎週 2 回の ペースで行い, 2016 年度は 2017 年 5 月 15 日まで, 2017 年度は 2018 年 4 月 30 日まで, 2018 年度は 2019 年 5 月 22 日まで実施した。2016年度は暖房機を用いない無加温促 成栽培とし，12月 1 日から 2 月 28 日まで透明ポリエチレン フィルムの 1 層カーテンで内張りした。 2017 年度と 2018 年度はヒートポンプを用いる加温促成栽培とし，12月 1 日から 2 月 28 日まで最低気温 $7^{\circ} \mathrm{C}$ 設定で加温した。 各年 度の $12 \sim 2$ 月の八ウス内に打影最低気温の平均は, 2016 年度は $3.1^{\circ} \mathrm{C}, 2017$ 年度は $5.0^{\circ} \mathrm{C}, 2018$ 年度は $6.2^{\circ} \mathrm{C}$ であった。試験規模は 1 区 12 株, 4 反復とした。

各年度の累積収量の推移を第 3 図に示す。2016年度は 花芽未分化苗を定植したこともあり，“真紅の美鈴”は 12 月末までの年内収量が少なかったものの, 無加温栽培にも かかわらず $1 \sim 2$ 月の厳寒期も一定のペースで累積収量が 増加し，5月 15 日までの総収量は“とちおとめ’と比べて 有意な差はみられなかった。 2017 年度の累積収量は年末 から 2 月にかけて直線的に増加し， 3 月以降は急激に増加 した．4月 30 日までの総収量は株当たり $700 \mathrm{~g}$ を超光，“と ちおとめ’の総収量を13\%上回った。2018年度は，5月 22 日までの総収量は同日に定植した“とち报とめ”之同等 であったが，この年度はいずれの品種も腋花房の出蕾が著 しく遅れ，第一腋花房の半数開花日が 1 月以降にずれ込ん だ (第 1 表)。この影響で，1月後半から 2 月中旬にかけて 収穫できる果実が極めて少ない状況となり, 総収量は前年
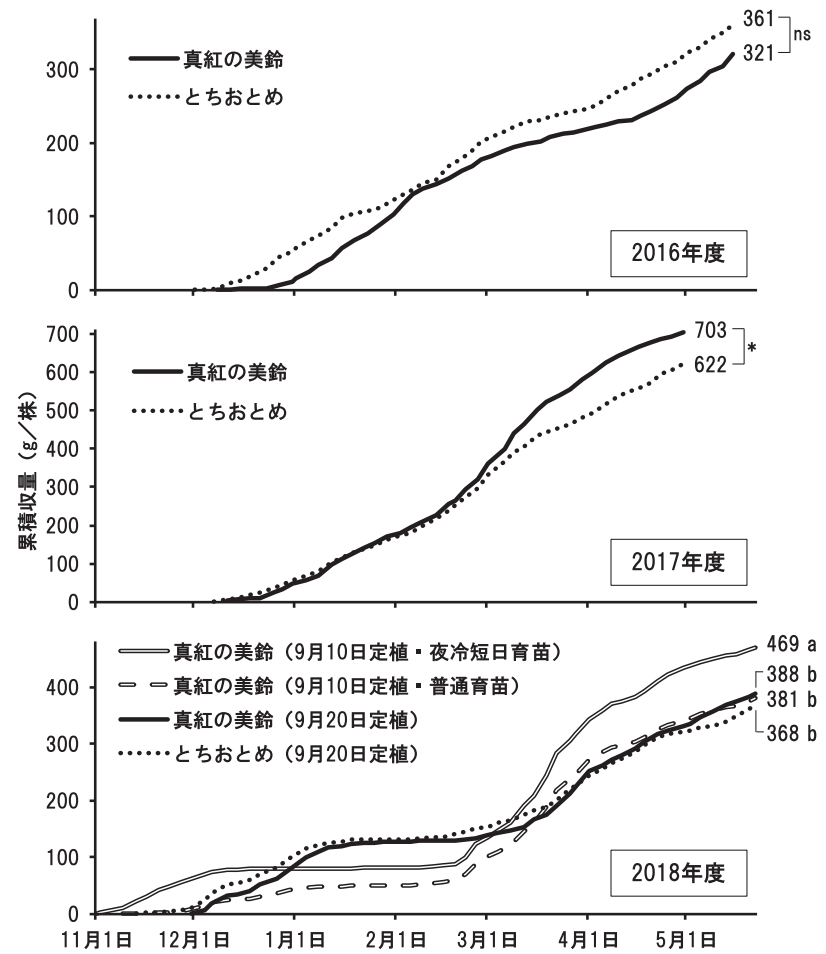

第 3 図 栽培年度別累積収量の推移

折れ線右側の数值は総収量を示す．*は $5 \%$ 水準で有意 差あり， $\mathrm{ns}$ は有意差なし（ $\mathrm{t}$ 検定， $\mathrm{n}=4)$ ）。た，異な るアルファベット間には $5 \%$ 水準で有意差あり（TukeyKramer 法, $\mathrm{n}=4$ )

比で 60\%程度にとどまった。夜冷短日育苗をした 真紅 の美鈴’は，12月上旬までに株当たり $100 \mathrm{~g}$ 弱の收量が得 られたが，その後は普通育苗の株と同様に收穫の中休及が 続いた。 2 月下旬以降は収量が急回復し, 総収量は普通育 苗の株を20\%程度上回った。

\section{4. 果実特性}

\section{1） 1 果重, 硬度および糖酸度}

2016２018年度の栽培に打ける ‘真紅の美鈴”の平均 1 果重は $15.7 \mathrm{~g}$ であった（第 2 表）。また，収穫した $15 〜$ $20 \mathrm{~g}$ 程度の完熟果（果面の概放 95\%が着色したもの）の硬 度を果実硬度計（KM-1，（株) 藤原製作所）で計測したと ころ，“真紅の美鈴”は ‘とち抢とめ’ と同等の硬さであっ た. 果汁の糖度をポケット糖酸度計（PAL-BX|ACID F5, (株)アタゴ) で測定し, 酸度を水酸化ナトリウム水溶液に よる中和滴定法で測定したところ，“真紅の美鈴”の12月 から 5 月までの平均糖度は $12^{\circ}$ 以上であり, 糖酸比は 20 以上であった (第 2 表).

\section{2) 糖組成}

糖の分析には $-80^{\circ} \mathrm{C}$ で凍結した $1 \sim 2 \mathrm{~g}$ の果実片（果頂 部を中心に放射状に切り出したもの）を供試し，約 $10 \mathrm{~mL}$ の $70^{\circ} \mathrm{C}$ に熱した $80 \%$ （v/v）エタノールを加光，さらに 標準物質として $5 \mathrm{mg}$ の meso-エリトリトールを加えてポ リトロンホモジナイザーで磨砕した。 これを時々混和しな がら $70^{\circ} \mathrm{C}$ に 10 分間置き，低分子の糖を抽出した，遠心分 


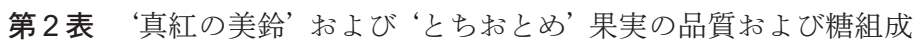

\begin{tabular}{|c|c|c|c|c|c|c|c|c|c|}
\hline \multirow{2}{*}{ 品種 } & \multirow{2}{*}{$\begin{array}{c}1{\text { 果重 }{ }^{z}}^{(\mathrm{g})}\end{array}$} & \multirow{2}{*}{$\begin{array}{c}\text { 硬度 } \mathrm{y,x} \\
(\mathrm{kg})\end{array}$} & \multirow{2}{*}{$\begin{array}{l}\text { 糖度 y } \\
\left({ }^{\circ} \text { Brix }\right)\end{array}$} & \multirow{2}{*}{$\begin{array}{c}\text { 酸度 }{ }^{\mathrm{w}} \\
(\%)\end{array}$} & \multirow{2}{*}{ 糖酸比 ${ }^{\mathrm{v}}$} & \multicolumn{4}{|c|}{ " 糖含量 ${ }^{\mathrm{y}}\left(\mathrm{mg} \cdot \mathrm{g}^{-1} \mathrm{FW}\right)$} \\
\hline & & & & & & グルコース & フルクトース & スクロース & 合計 ${ }^{u}$ \\
\hline 真紅の美鈴 & 15.8 & 0.49 & 12.1 & 0.59 & 20.5 & 26.5 & 23.3 & 32.7 & 82.5 \\
\hline とちおとめ & 17.1 & 0.46 & 11.5 & 0.62 & 18.5 & 19.4 & 17.0 & 42.6 & 79.0 \\
\hline 分散分析 ${ }^{\mathrm{t}}$ & ns & $\mathrm{ns}$ & $\mathrm{ns}$ & ns & - & $*$ & $*$ & $*$ & ns \\
\hline \multicolumn{10}{|c|}{ 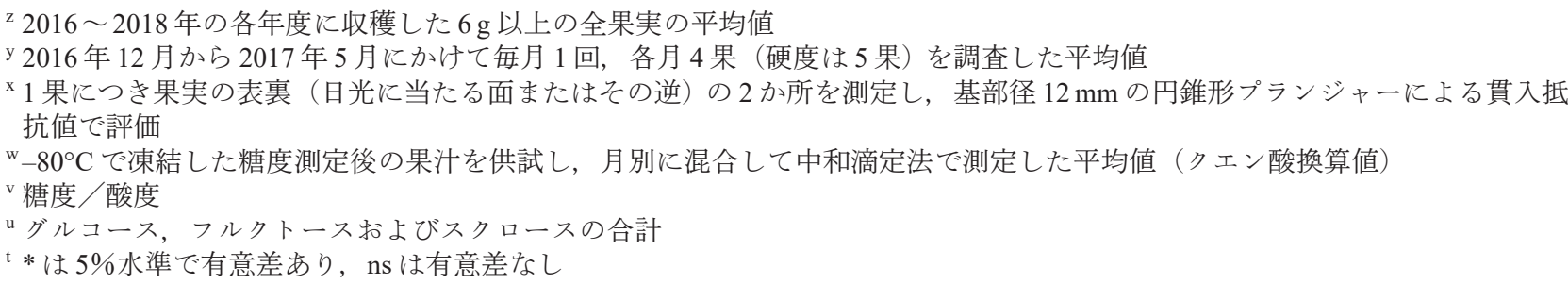 } \\
\hline
\end{tabular}

離後の上清を, Tateishi ら（2004）の方法に従って高速液 体クロマトグラフィー（HPLC，Prominence，（株）島津製 作所）で分析した. カラムはNH2P50 4E (昭和電工(株)), 温度は $30^{\circ} \mathrm{C}$ ，移動相は $70 \%(\mathrm{v} / \mathrm{v})$ アセトニトリル，流速 は毎分 $1 \mathrm{~mL}$ と, 示差屈折率検出器 RID-20A（(株)島津 製作所）を用いて検出した。 ‘真紅の美鈴’の糖組成はグ ルコース，フルクトース，スクロースの3 種類が主体であ り，‘とち拈とめ’と比べて還元糖であるグルコースとフ ルクトースの割合が高く，非還元糖であるスクロースの割 合が低かった（第2 表).

\section{3）果皮色}

ハンディ型分光色差計 (NF555, 日本電色工業(株), 測 定面積 $4 \mathrm{~mm}$ 径) を用いて果実赤道面の色を $\mathrm{L} * \mathrm{a} * \mathrm{~b} *$ 表色系 で評価したところ，“真紅の美鈴’は明度 ( $\mathrm{L}^{*}$ 值 $)$ が ‘と ち拈とめ’, ‘麗紅’, ‘ふさの香”, “紅ほっぺ’, ‘さちのか’ のいずれよりも低く，相対的に暗い色であった（第 3 表）. また， $\mathrm{a}$ *值と b*值がよりゼロに近く彩度が低かったこと から, “真紅の美鈴”の果皮色は独特であり，その両親で ある ‘岕の香”と ‘麗紅”を含む他品種との区別性が高 いことが裏付けられた。

第3 表 分光色差計による果面色の比較

\begin{tabular}{|c|c|c|c|c|}
\hline \multirow{2}{*}{ 品種 } & \multirow{2}{*}{ 明度 z,y } & \multicolumn{2}{|c|}{ "色空間座標 ${ }^{z}$} & \multirow{2}{*}{ 彩度 ${ }^{x}$} \\
\hline & & $a^{*}$ & $b^{*}$ & \\
\hline 真紅の美鈴 & 21.5 & 23.0 & 13.5 & 26.7 \\
\hline とち拈とめ & $25.6 * \mathrm{w}$ & $30.0 *$ & $21.8 *$ & $37.1 *$ \\
\hline 麗紅 & $26.3 *$ & $30.7 *$ & $22.7 *$ & $38.2 *$ \\
\hline ふさの香 & $28.1 *$ & $30.2 *$ & $21.9 *$ & $37.4 *$ \\
\hline 紅ほっぺ & $25.5 *$ & $31.2 *$ & $22.6 *$ & $38.6 *$ \\
\hline さちのか & $25.5 *$ & $31.9 *$ & $19.4 *$ & $37.4 *$ \\
\hline
\end{tabular}

z 2018 年 12 月 25 日に収穫した各品種 10 果の完熟果を供試 し，1果につき果実の表裏を含む 4 か所の果実赤道面の色 を測定した平均值

$\mathrm{y}$ 明度 $=\mathrm{L}^{*}$

$\mathrm{x}$ 彩度 $=\left(\mathrm{a}^{* 2}+\mathrm{b}^{* 2}\right)^{1 / 2}$

w*はDunnett 法により“真紅の美鈴”と比較して $5 \%$ 水準で 有意差あり, ns は有意差なし

\section{4）アントシアニン組成}

アントシアニン色素の分析には, 凍結した $1 \sim 2 \mathrm{~g}$ の果 実片と，果実から分離した果皮（瘦果を含む）と果肉をそ れぞれ供試した。サンプル 10 倍量 $(\mathrm{v} / \mathrm{w})$ の $50 \%(\mathrm{v} / \mathrm{v})$ 酢酸に浸してアントシアニンを抽出し, HPLCで分析した. カラムの種類, 温度, 移動相拈よび流速は渡辺ら（2014） の方法に従い，フォトダイオードアレイ検出器 SPD-M20A （(株）島津製作所）を用いて $520 \mathrm{~nm}$ の波長を検出した. アントシアニンの量はシアニジン 3-グルコシドで作成し た検量線を用いて換算した。

イチゴ果実に含まれるアントシアニン色素は, ペラルゴ ニジンまたはシアニジンの配糖体が主成分であることが 知られている (da Silva ら，2007; Yoshida ら，2002). “真紅 の美鈴”のアントシアニンは，クロマトグラム上に括いて

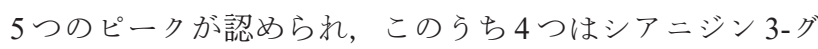
ルコシド (Cy 3-glc), ペラルゴニジン 3-グルコシド $(\mathrm{Pg}$ 3-glc), ペラルゴニジン3-ルチノシド (Pg 3-rut), ペラル ゴニジン 3-マロニルグルコシド (Pg 3-maglc) によるもの と推定された（第4図A）。“真紅の美鈴’ はPg 3-glc, Pg 3-maglc, Cy 3-glc の順に多く含んで抢り，これらの構成比

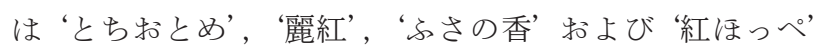
と概水同等だった（第 4 図B）。一方，“真紅の美鈴’ に拈 いて検出されたアントシアニン 5成分の合計含量は果実 $1 \mathrm{~g}$ 当たり $185 \mu \mathrm{g}$ であり, これは“とち拈とめ’の 2.8 倍, ‘ふさの香”, ‘麗紅’, “紅ほっぺ’执よび ‘さちのか’の約 2 倍にのぼった。 また，“真紅の美鈴”の果皮と果肉に抢け る 5 成分の含量をそれぞれ定量したところ，果皮 $1 \mathrm{~g}$ 当た りの合計含量は $435 \mu \mathrm{g}$ に達し, 果肉 $1 \mathrm{~g}$ 当たりの含量 $97 \mu \mathrm{g}$ の 4.5 倍であった. また， “真紅の美鈴”と“とち拈と め’の部位別に 5 成分の含量を比較すると, 果皮では“真 紅の美鈴’の方が 2.5 倍多く，果肉では 3.9 倍多かった. 一方，アントシアニンの構成比を部位間で比べると，両品 種とも果皮ではCy 3-glc の割合が相対的に低かった．以上 のように, アントシアニンの構成比には品種や果実の部位 によって多少の差異がみられるものの, いずれもペラルゴ 


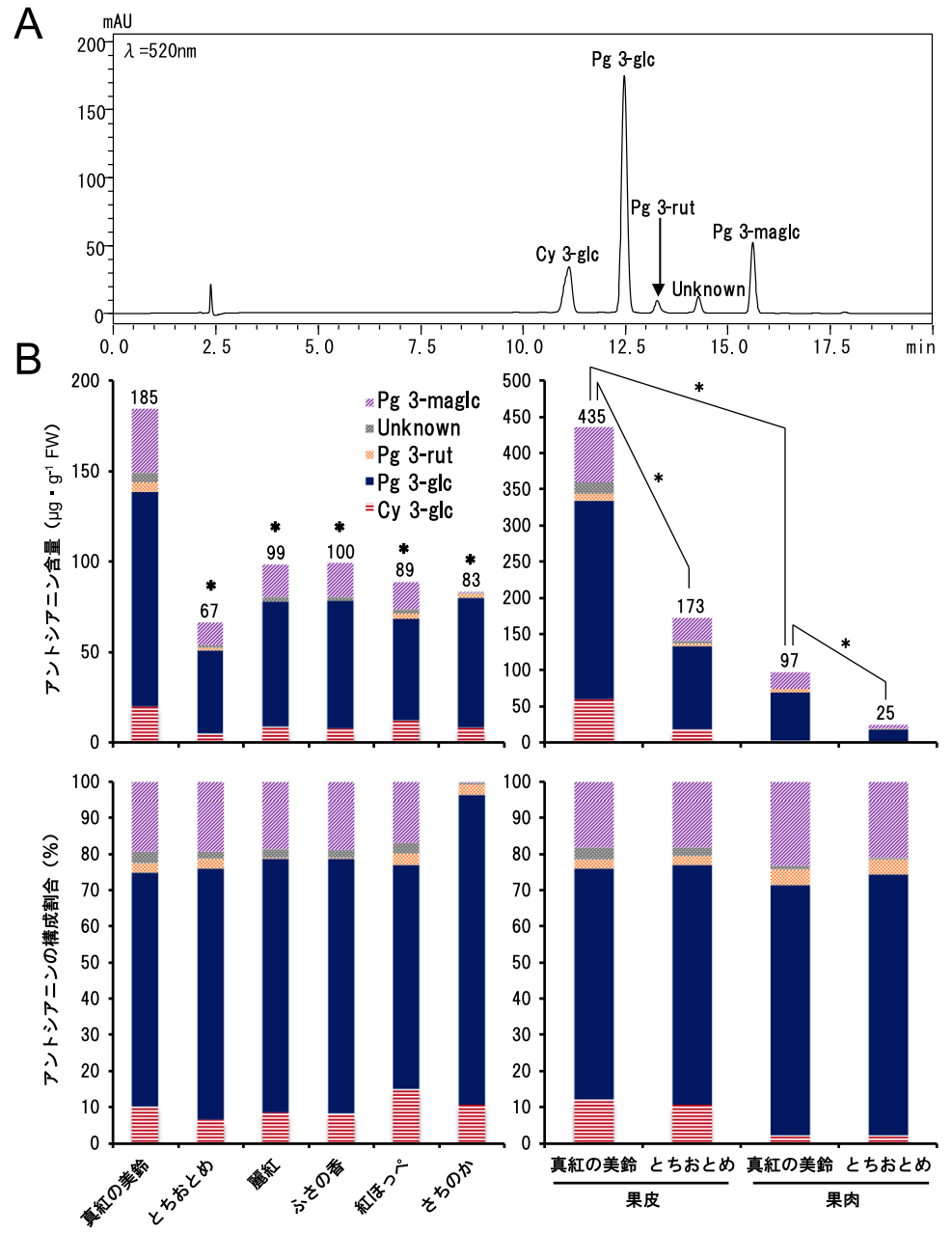

第4図 イチゴ果実のアントシアニン色素

A：‘真紅の美鈴’ 果実から抽出したアントシアニン色素のクロマトグラム

B：アントシアニン色素の組成拉よびその構成割合

左側のグラフは果実の切片から抽出した色素, 右側のグラフは分離した果皮と果肉からそれぞれ抽出した色素を示す。 グラフバー上の数值は新鮮重 $1 \mathrm{~g}$ 当たりの色素 5 成分の合計含量 $(\mu \mathrm{g})$ を示し，*は $5 \%$ 水準で有意差があることを示す （左上のグラフは ‘真紅の美鈴”を対照としたDunnett法，右上のグラフはt検定，いずれも $\mathrm{n}=6$ ）

Cy 3-glc : シアニジン3-グルコシド, Pg 3-glc : ペラルゴニジン3-グルコシド, Pg 3-rut : ペラルゴニジン 3-ルチノシド, Pg 3-maglc : ペラルゴニジン 3-マロニルグルコシド

ニジン配糖体が全体の $80 \%$ 以上を占めていた。

\section{5）抗酸化活性および総ポリフェノール含量}

アントシアニンはポリフェノールの一種であり，活性酸 素を除去する高い抗酸化活性があることが知られている (Kähkönen・Heinonen, 2003). そこで, “真紅の美鈴’を含 む6 品種のイチゴ果汁に打ける抗酸化活性およびポリフェ ノール含量を調査した．分析では完熟果を 3 果まとめて圧 搾し，軽く遠心分離して固形物を除いた後の果汁を供試し た. 抗酸化活性の測定はDPPH 法（Ratty ら，1988）を用い て行った. $20 \mu \mathrm{L}$ の果汁に $1.98 \mathrm{~mL}$ の $0.1 \mathrm{mM} \mathrm{2,2-ジフェニ}$ ルー1-ピクリルヒドラジル (DPPH) エタノール溶液を添加 して混和し, 遮光下で 20 分間静置した後, $517 \mathrm{~nm}$ の吸光 度を測定した。検量線はアスコルビン酸ナトリウム水溶液 で作成し，DPPH ラジカル消去活性の当量を求めた. 総ポ リフェノール含量の測定はフォーリンーチオカルト法
（O’Sullivan・Mathison, 1970）を用いて行った. $25 \mu \mathrm{L}$ の果 汁に $1.5 \mathrm{~mL}$ の蒸留水, $125 \mu \mathrm{L}$ の フノール試薬（ナカラ イテスク(株))， $375 \mu \mathrm{L}$ の 10\%（w／v）炭酸ナトリウム水 溶液を順に加えて混合し，8分間静置した。 さらに $950 \mu \mathrm{L}$ の蒸留水を加えて混合し, 室温で 2 時間静置した後, $765 \mathrm{~nm}$ の吸光度を測定した。検量線はカテキン水溶液で 作成した。

“真紅の美鈴” の抗酸化活性は同品種の片親にあたる ‘る さの香より高く, 総ポリフェノール含量はもら一方の片 親にあたる ‘麗紅’ と，“ふさの香”物よび “紅ほっぺ’の 3 品種と比べて高かった（第４表）。な拈，“とち拈とめ’, ‘さちのか’ との比較では，抗酸化活性执よび総ポリフェ ノール含量のいずれにも有意な差はみられなかった。

\section{5. 普及状況}

“真紅の美鈴” の品種利用権の許諾実績から推測すると, 
第 4 表 イチゴ果汁の抗酸化活性と総ポリフェノール含量

\begin{tabular}{lcc}
\hline \hline 品種 & $\begin{array}{c}\text { 抗酸化活性 } \\
\left(\mu \mathrm{mol} \text { アスコルビン酸当量・ } \mathrm{mL}^{-1}\right)\end{array}$ & $\begin{array}{c}\text { 総ポリフェノール含量 } \\
(\mu \mathrm{g}\end{array}$ \\
\hline 真紅のテキ美鈴 & 5.7 & 1,167 \\
とち技とめ & $6.0 \mathrm{~ns}^{\mathrm{y}}$ & $1,210 \mathrm{~ns}$ \\
麗紅 & $5.1 \mathrm{~ns}$ & $1,017 *$ \\
ふさの香 & $4.8 *$ & $1,003 *$ \\
紅ほっぺ & $5.2 \mathrm{~ns}$ & $965 *$ \\
さちのか & $5.4 \mathrm{~ns}$ & $1,104 \mathrm{~ns}$ \\
\hline
\end{tabular}

${ }^{z} 2018$ 年 3 月 15 日に収穫した $15 \sim 20 \mathrm{~g}$ の完熟果を対象に, 3 果ずつまとめて抽出した果汁 6 セットを調査した平均値

$\mathrm{y} *$ * Dunnett 法により ‘真紅の美鈴”と比較して $5 \%$ 水準で 有意差あり, ns は有意差なし

2018 年の生産軒数は約 50 軒であり, 許諾先の大半は千葉 県内の生産者である。千葉県では, 生産果実のほぼ全量が 直売拈よび観光摘みとり用途汇利用されて扔り, 市場出荷 は基本的に行われていない. 果皮拉よび果肉が極めて濃い 赤色を呈することが他品種との差別化に貢献している．こ の果色のインパクトが強い上，市場流通していないことか ら希少性が高く，千葉県内の直売所では ‘とち拈とめ’な ぞの従来品種よりも高值で取引されている。なお，2019 年時点では ‘真紅の美鈴”の苗を市販して扔らず，利用を 希望する生産者には育成者権者である成川と許諾契約を 結んだ上で個別に苗を提供している。

\section{6. 考察}

‘真紅の美鈴’ はアントシアニン色素を多く含む濃赤色 果を特徵とする新品種である. 果実は平均糖度が 12 ○を超 光, 食味の指標となる糖酸比が 20 を上回り, 還元糖の> ルクトースとグルコースを比較的多く含んでいる。 スク ロースやグルコースは温度によらず一定の甘味を呈するの に対し, フルクトースは低温下で甘味が増す性質が強いこ とから（岡本・吉田，2014），フルクトースが多い “真紅 の美鈴’の甘味を際立たせるには果実が冷えた状態で食す ことが重要である。販売時に冷やした果実を試食させる, 収穫体験型観光農園であれば果実温度が上がらない午前中 に食させるなどの工夫を行らことで，本品種の食味の評価 がさらに高まると考兄られる。また，“真紅の美鈴”は育 成当初から輸送性を考慮して果実の硬さを選拢基準に加兄 て抢り，実際に“とち抢とめ”並の硬度があることから， 市場出荷向けのパッキングや消費地への輸送にも対応でき ると予想される。一方，“真紅の美鈴” は個人で育成した 品種であるため，公的機関や民間会社が育成した品種と比 ベてプロモーションカが弱いことが課題であり, 市場出荷 のためには宣伝やブランド化を進めて生産者・消費者双方 の認知度を高めるとともに, 産地ぐるみでの安定出荷体制 を整備することが求められる.

一方，“真紅の美鈴” $は$ 花芽分化が ‘とち沶とめ’よりや や遅く, 花芽未分化苗の定植は開花や収穫開始の遅孔を招 いた。葉県内の産地に打いても, 本品種を9 月20日よ
り前に定植すると開花の遅れやばらつきが生じることがあ るため, 南関東地域に扔ける本品種の定植適期は 9 月 20 日頃以降であると考兄られる。 また, 他の一季成り性品種 と同様に，夜冷短日育苗が花芽分化の早期誘導に有効であ ることから，秋の早い時期に収穫する早出し栽培にも対応 できる。なお，2018年度は品種，定植日および短日夜冷 処理の有無に関わらず第一腋花房の開花が遅れて収穫の中 休みが生じたが，この年度には千葉県大網白里市で栽培し た ‘とち抢とめ’や“真紅の美鈴”を含む一季成り性品種 全般に打いても同様の中休及が確認されている，2018年 は第一腋花房分化期にあたる 10 月が温暖であったため, 腋花房の分化が妨げられて中休反が生じたものと推測され る。一方，観光摘みとり用途では必ずしも促成作型による 早出しを行う必要はなく, 営業が本格化する 1 月以降の収 量を安定化させることが重要である. ‘真紅の美鈴”の花 芽未分化苗を定植して無加温栽培した 2016年度の試験で は，1〜2月に一定のペースで収量が増加したことから， 観光農園では未分化苗定植や無加温栽培を一部のハウスに 導入することで，腋花房分化の遅延による中休久のリスク を低減できる可能性がある.

“真紅の美鈴”果実に含まれるアントシアニン色素はぺ ラルゴニジン配糖体が組成の $90 \%$ を占め, 色素成分の構 成比は従来品種の ‘ちち打とめ’や“紅活っぺ” と変わら なかった（第4図B）、このことから，“真紅の美鈴”が濃 赤色を呈するのはアントシアニンの組成の違いによるもの ではなく，果皮や果肉に含ま机る色素の絶対量が多いため と考光られる. Yoshidaら（2002）も，イチゴの果色には アントシアニンの組成よりも含量の方が大きく影響するこ とを示して打り，我々の結果もこの知見に沿うものであ る.一方，“真紅の美鈴” は，その親である ‘らさの香” と “麗紅’のいずれよりもアントシアニンの含量が多かった ことから，“真紅の美鈴’のゲノムには双方の親に由来す るアントシアニン合成に働く遺伝子座が集積されて拈り, その結果として両親を上回る多量の色素を蓄積するものと 推測される.

アントシアニンは抗酸化活性のあるポリフェノールの一 種であり，“真紅の美鈴’ はアントシアニンを多く含むこ とから高い抗酸化活性を示すことが期待されたが，アント シアニン含量が同品種の $40 \%$ 未満である ‘ちち扔とめ’ と 比較しても, 果汁の抗酸化活性に有意な差はみられなかっ た．品種ごとの抗酸化活性の高低は総ポリフェノール含量 の多少と概称一致して打り (第4 表)，“真紅の美鈴”之 ‘とち打とめ’の総ポリフェノール含量は同等であること から, 結果として抗酸化活性に差が生じなかったと考㝋ら れる，曽根ら（2017）は，イチゴの抗酸化活性に打ける抗 酸化成分の寄与度を明らかにして拈り，ポリフェノールの 一種であるエラグ酸の寄与度が 8 品種の平均で $68 \%, \quad ア$ スコルビン酸が $21 \%$ ， アントシアニンが $11 \%$ と算出して いる. このことも, 果実全体の抗酸化活性におけるアント 
シアニンの寄与が限定的であることを示している。一方， アントシアニンの機能性として, 様々ながん, 心疾患, 神 経変性疾患, 糖尿病执よび代謝系疾患の抑制作用がヒトの 臨床試験や疫学研究を含む実験で明らかにされているが, これらの健康増進効果は抗酸化作用によるものだけではな く, アントシアニン自体が細胞内シグナル伝達や抗炎症経 路などに作用するためと考えられている（Lilaら，2016）. 個別の食品の機能性は科学的根拠に基づく議論が必要であ るものの，アントシアニンを多く含む ‘真紅の美鈴” の機 能性を示すことができれば，果実やその加工品の付加価值 向上につながると期待される.

\section{摘 要}

アントシアニン色素を多く含み，果実が濃赤色を呈する 促成栽培用イチゴ品種 “真紅の美鈴”を育成した。神奈川 県に打ける試験栽培に拈いて，本品種は“とち拈とめ’よ り花芽分化がやや遅く, 定植適期は 9 月 20 日頃以降であ

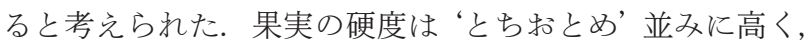
糖酸比は20を超え，還元糖のグルコースとフルクトース を比較的多く含んでいた．果実のアントシアニン色素の含 量は新鮮重 $1 \mathrm{~g}$ 当たり $185 \mu \mathrm{g}$ であり，母親の ‘ふさの香” および父親の“麗紅”の約 2 倍，“とちおとめ’の約 3 倍で あった。一方，果汁の抗酸化活性には “真紅の美鈴” と従 来品種で大きな差はみられず，アントシアニンの抗酸化活 性への寄与度は低いと推定された. アントシアニンの組成 はペラルゴニジン配糖体が $80 \%$ 以上を占めて拈り，検出 された 5 成分の構成比は ‘とち扤とめ’や親品種と概水同 等であった，このことから，“真紅の美鈴’が濃赤色を呈 するのはアントシアニン組成の影響ではなく, 色素の含量 が顕著に多いためと考えられた。

謝 辞 本研究の実施に当たり，栽培，調査および実験 に協力いただいた日本大学生物資源科学部の学生, 特に神 山拓也氏，野口琴未氏，佐々木龍之介氏に感謝いたします。

\section{引用文献}

da Silva, F. L., M. T. Escribano-Bailón, J. J. P. Alonso, J. C. Rivas-Gonzalo and C. Santos-Buelga. 2007. Anthocyanin pigments in strawberry. LWT-Food Sci. Technol. 40: 374382.

Kähkönen, M. P. and M. Heinonen. 2003. Antioxidant activity of anthocyanins and their aglycons. J. Agric. Food Chem. 51: 628-633.

Lila, M. A., B. Burton-Freeman, M. Grace and W. Kalt. 2016. Unraveling anthocyanin bioavailability for human health. Annu. Rev. Food Sci. Technol. 7: 375-393.

成川 昇・石橋光治・荻原佐太郎・土岐知久。1981。 イチ ゴ新品種「麗紅」の育成経過と特性. 千葉農試研報. 22: $45-55$.

野口裕司・森下昌三・室 崇人・小島昭夫・坂田好輝・山 田朋宏・杉山慶太．2011．芳香性イチゴ 10 倍体種間 雑種品種 “桃薰” の育成とその特性. 野菜茶研報. 10: $59-67$.

岡本洋子・吉田惠子. 2014. 甘味感受性に及ぼす温度の影 響. 調科誌. 47: 97-102.

O'Sullivan, J. and G. E. Mathison. 1970. Interference by monosaccharides with the estimation of tyrosine and proteins using the Folin-Ciocalteu phenol reagent. Anal. Biochem. 35: $540-542$.

Ratty, A. K., J. Sunamoto and N. P. Das. 1988. Interaction of flavonoids with 1,1-diphenyl-2-picrylhydrazyl free radical, liposomal membranes and soybean lipoxygenase-1. Biochem. Pharmacol. 37: 989-995.

曽根一純・沖村 誠・北谷恵美・木村貴志. 2017. アスコ ルビン酸含量が多く抗酸化活性の高い促成栽培用イチ ב゙新品種「执い Cベリー」，九州沖縄農研七報。 66: 66-86.

Tateishi, A., T. Nakayama, K. Isobe, K. Nomura, K. Watanabe and H. Inoue. 2004. Changes in sugar metabolism enzyme activities in cultivars of two pumpkin species (Cucurbita maxima and C. moschata) during fruit development. J. Japan. Soc. Hort. Sci. 73: 57-59.

Yoshida, Y., N. Koyama and H. Tamura. 2002. Color and anthocyanin composition of strawberry fruit: Changes during fruit development and differences among cultivars, with special reference to the occurrence of pelargonidin 3 malonylglucoside. J. Japan. Soc. Hort. Sci. 71: 355-361.

渡辺慶一・土屋正邦・立石 亮・井上弘明. 2014. クラン ベリー果実のアントシアニン，カロテノイド色素. 食 生誌. 25: 137-140. 